\title{
Pharmacological Evaluation of Selected Medicinal Plants Used in the Management of Oral and Skin Infections in Ebem-Ohafia District, Abia State, Nigeria
}

\author{
Blessing O. Oyedemi, ${ }^{1}$ Sunday O. Oyedemi $\mathbb{D}^{2}{ }^{2}$ Johnson V. Chibuzor, ${ }^{1}$ Ifeoma I. Ijeh, ${ }^{2}$ \\ Roger M. Coopoosamy, ${ }^{3}$ and Ayobami O. Aiyegoro ${ }^{4}$ \\ ${ }^{1}$ Department of Plant Science and Biotechnology, Michael Okpara University of Agriculture, Umudike, Nigeria \\ ${ }^{2}$ Department of Biochemistry, Michael Okpara University of Agriculture, Umudike, Nigeria \\ ${ }^{3}$ Department of Nature Conservation and Ethnobotany, Mangosuthu University of Technology, P.O. Box 12363, Jacobs, \\ Durban 4026, South Africa \\ ${ }^{4}$ GI Microbiology and Biotechnology Unit, Agricultural Research Council, Animal Production Institute, Irene, \\ Pretoria 0062, South Africa \\ Correspondence should be addressed to Sunday O. Oyedemi; silvanusdemi@gmail.com
}

Received 24 January 2018; Accepted 26 April 2018; Published 4 July 2018

Academic Editor: Carlos H. G. Martins

Copyright (C) 2018 Blessing O. Oyedemi et al. This is an open access article distributed under the Creative Commons Attribution License, which permits unrestricted use, distribution, and reproduction in any medium, provided the original work is properly cited.

Oral and skin infections contribute significantly to the global health challenges responsible for the current trend of increased morbidity and premature death. The purpose of this study was to document medicinal plants used in the management of oral and skin infections in Ebem-Ohafia Local Government Area (LGA), Abia State, and to characterize the in vitro antioxidant and antibacterial activity. The thin layer chromatography (TLC) profiling of ten of the selected folklore medicine was carried out using a various solvent system of different polarity index. The antioxidant capacity of the plant extracts was evaluated using chemicalbased methods, and its antibacterial effect was investigated using disc diffusion and microdilution methods. Sixty-one plant species belonging to 26 families were discovered, and the most frequently cited species are Euphorbiaceae (18.03\%), Fabaceae (11.47\%), and Asteraceae (11.47\%). All the plant extracts showed a promising free radical scavenging activity and efficient ferric reducing antioxidant power in a concentration-dependent manner possibly due to their richness in polyphenol with TLC profiling showing maximum three bands of phytochemicals. Also, the plant extracts exhibited a mild to weak antibacterial activity against our panel of bacterial strains having MIC values ranging from 256 to $>512 \mu \mathrm{g} / \mathrm{mL}$ reflected in their zone of inhibition at $10 \mu \mathrm{g} /$ disc. The data obtained for Breynia nivosa (BN), Eleusine indica (EI), Cassia alata (CA), Chromolaena odorata (CO), and Acalypha hispida $(\mathrm{AH})$ extracts substantiate the traditional use of these herbal remedies in the region and open the possibility for the development of cheaper and affordable drugs in the treatment of oral and skin infections. Further studies are needed to identify active ingredient with strong antibacterial and antioxidant capacities along with their molecular mechanisms.

\section{Introduction}

Oral health is a state of being free from the mouth and facial pain, throat cancer, oral infection, and sores that limit human capacity in biting, chewing, smiling, and speaking as well as psychosocial well-being [1]. Owing to the environmental pollution, the concentration of heavy metals such as $\mathrm{Ni}, \mathrm{Cr}$, $\mathrm{Zn}, \mathrm{Hg}$, and $\mathrm{Pb}$ in most food materials and water is rapidly increasing which severely affects both oral and general health condition. For example, dental caries, periodontitis, and throat cancer have been recognised as the most prevalent noncommunicable diseases associated with heavy metals, globally affecting school-aged children and a huge majority of adults [2]. In Nigeria, the rate of deep periodontal pocket is between 15 and $58 \%$ (aged 15 years) while the prevalence of unmanaged dental caries is high raising alarm for 
odontogenic infection. Falsetta and colleagues [3] highlighted that poor oral hygiene and frequent consumption of sugars create bacterial adhesion to tooth surfaces via mineralization and biofilm formations caused by glucosyl and fructosyl transferases. The same authors indicated an adverse effect of higher concentration of fluoride in drinking water in some developing countries that is responsible for the cause of fluorosis and dental caries regardless of age and sex. The oral cavity exposed to carcinogens that may advance into precancerous lesions and malignant disorders like leukoplakia, submucous fibrosis, and dental caries resulting from the imbalance in the levels of free radicals generation and natural antioxidants in the saliva [4]. There is a growing consensus that administration of natural antioxidants to the oral cavity reduces free radicals, oxidative stress, and oral inflammation triggered by nicotine, alcohol, and other toxins introduced into the mouth [5].

The skin, being the largest organ in the body, guards the underlying muscles, bones, ligaments, and internal organs interfaces with the environment, as well as protecting the body against pathogenic microbes [6]. Notwithstanding, infectious skin diseases such as skin abrasions, burns, acne, dermatitis, and sebaceous cysts have become everyday incidences and constitute a reoccurring health problem that affects all human age groups [6]. Over the years, bacterial skin disorders such as impetigo, ecthyma, folliculitis, eczemas, and urticarias are one of the most common causes of hospital visits in the southeastern part of Nigeria. Overcrowding, malnutrition and humidity, heat, food, and medication allergies cause some of these skin diseases, especially among the school children in urban and rural settings [2]. Microbial invasion of the skin surface forms a biofilm that confers a drug tolerance on the bacteria and capacity to escape host immune response [7]. The discovery of antibiotic resistance genes in several microorganisms, quorum sensing, and horizontal gene transfer has limited treatment of skin and soft tissue infections and thus could pose a serious health challenge in a region where there is limited access to microbiological laboratory facilities and antimicrobial agents [8]. The global need for effective alternative medicines for oral and skin infections with minimal side effects and economical use is increasing due to the rapid growth of antibiotic resistance and opportunistic infections in immunocompromised patients [9].

Plant-derived products are now gaining recognition worldwide currently recommended for primary healthcare, but only a few plants have received rigorous scientific investigation. Medicinal plants are natural products used since time immemorial for the treatment of various human diseases. All over the world, the citizen and health practitioners are now starting to rely on herbal medicines as a substitute for scientifically proved therapies [10]. Herbal products contained secondary metabolites that are synthesized through the pentose phosphate, shikimic acid, and phenylpropanoid pathways. These compounds play a significant defensive role against pathogenic bacteria and oxidative stress caused by abiotic stress in plant [11]. Currently one of the strategies used to treat skin and oral infections is the use of natural products from plant origin perhaps due to the perception that long-term use of western medicine induces severe complications. Consequently, many Nigerian patients, in particular, those living in the rural areas, have resorted to seeking relief via traditional healers and herbalists who administer herbal drugs in the management of human diseases. Considering the rate at which the vegetation gets depleted and the current focus on safe complementary and alternative medicine to synthetic drugs, there is, therefore, the need to document the indigenous knowledge of these plants and to search for more plants with therapeutic potential in the treatment of bacterial infections and oxidative stress.

There is a paucity of literature in traditional medicine used in the management of orofacial and skin infections in Nigeria. Our recent ethnobotanical survey conducted in Ebem-Ohafia LGAs in the southeastern part of Nigeria revealed sixty-one plant species commonly used in the management of oral and skin infections. Despite the acclaimed traditional use of these botanicals as therapeutic agents, there is little scientific evidence to support their folkloric use. Therefore, this study aimed at investigating the antioxidant capacity of these herbal remedies in terms of free radical scavenging, reducing power, and total phenolic and flavonoid content in consonance with the TLC profiling. The antibacterial effect on some clinically isolated bacteria associated with oral and skin infections was also investigated.

\section{Materials and Methods}

2.1. Study Area. Ebem-Ohafia is a town in Ohafia LGA of Abia state in the southeastern part of Nigeria situated between $5^{\circ} 38^{\prime} \mathrm{N}$ and $7^{\circ} 50^{\prime}$ East and encompasses over twenty-six hometowns with a population of over 300, 000 from the last population census in 2006. Ebem community is a part of the tropical rainforest characterized by dry and rainy season with a total annual rainfall of over $1400 \mathrm{~mm}$ and an annual temperature range of $23^{\circ} \mathrm{C}$ to $32^{\circ} \mathrm{C}$. The people of the region practice subsistence farming under local government agencies policy. The inhabitants of Ebem use herbal drugs either alone or in combination with other medicines in the treatment of human diseases. Most of the people in Ebem are rural dwellers; hence they use plant-based therapies in the management of ailments that include oral and skin infections.

2.2. Ethnobotanical Survey. The ethnobotanical survey was conducted between December and May 2016 using a wellstructured questionnaire administered to the participants with indigenous knowledge of plants utilized in the area. The set questions contained the local diagnosis of oral and skin diseases, the name of plant samples used for the treatment, methods of preparation, and duration of treatment, side effects, and mode of administration. The people interviewed consisted of women and men both married and unmarried at the age of 30 to 65 with little education qualification.

2.3. Plant Collection and Identification. The leaves of Ipomoea involucrata (II), Acalypha hispida (AH), Breynia nivosa (BN), Jatropha curcas (JC), Chromolaena odorata (CO), Macrolobium macrophyllum (MM), Baphia nitida (BNI), Burkea africana (BA), Cassia alata (CA), and the root of Eleusine 
indica (EI) were collected after the interview. The plants were identified by their local names and authenticated by Mr. Oriaku Williams and Professor Gabriel Osuagwu from the Department of Plant Science and Biotechnology, College of Natural Sciences, Michael Okpara University of Agriculture, Umudike in Abia state, Nigeria. The vouchers specimens (VICJON 1-10) were prepared and deposited at the departmental herbarium. The preparations and mode of intake of the herbal remedies are described in Table 1.

2.4. Sample Preparation. We collected leaves and roots of the ten plants that were frequently mentioned in the survey and oven-dried at $40^{\circ} \mathrm{C}$ for $72 \mathrm{~h}$ while the root of EI was dried longer for seven days. The dried plant materials were pulverized to a fine powder using an electric blender and stored in an airtight container for further use. Thirty grams $(30 \mathrm{~g})$ of dried powdered materials were extracted with 150 $\mathrm{mL}$ of $100 \%$ methanol for $48 \mathrm{~h}$ on a mechanical shaker (Stuart Scientific Orbital 20.2, SOSI, Essex, UK) and the extracts were filtered using Buchner funnel and Whatman Number 1 filter paper. The filtrate was concentrated using a rotary, evaporated at $40^{\circ} \mathrm{C}$ to recover the solvent, and air-dried in a fume chamber to give a yield ranging from 4.5 to $8.3 \mathrm{~g}$.

2.5. Thin Layer Chromatography (TLC) Profile. Thin layer chromatography is a simple method for analyzing a complex mixture of compounds based on the distance travelled. The plant extracts $(1 \mathrm{mg} / \mathrm{mL})$ dissolved in methanol and spotted on the plate coated with silica gel 60 F254 as a stationary phase. The slurry was prepared by dissolving $15 \mathrm{~g}$ of silica gel $60 \mathrm{~F} 254$ in $30 \mathrm{~mL}$ of distilled water and immediately poured into the plate. The plates were air-dried overnight. About $10 \mu \mathrm{L}$ of the plant extracts was gently loaded on the base of the plate ( $5 \mathrm{~cm}$ above) using the capillary tube. The plates were allowed to develop in chromatographic tanks consisting of three different solvents (mobile phase) chloroform: methanol: acetic acid (5:4:1) until they reach $3 / 4$ th of the TLC plate. The TLC plate was removed and allowed to dry, the spots were detected by iodine vapour, and retention factor $\left(R_{f}\right)$ was calculated using the equation: $R_{f}$ $=$ distance travelled by the components/distance travelled by the solvent.

2.6. Total Phenolic Content (TPC) Assay. The total phenolic content present in these extracts was quantified by the Folin Ciocalteu reagent (FCR), using the method of Ghaffari et al. [12]. Briefly, $0.2 \mathrm{~mL}$ of the plant extract $(2 \mathrm{mg} / \mathrm{mL})$ was added to the reaction mixture consisting of $1 \mathrm{~mL}$ of $10 \% \mathrm{v} / \mathrm{v}$ FCR and $0.8 \mathrm{~mL}$ of $\mathrm{Na}_{2} \mathrm{CO}_{3}(0.075 \mathrm{mg} / \mathrm{mL})$ to give a final concentration of $0.2 \mathrm{mg} / \mathrm{mL}$ of each extract. The resulting mixture was incubated at $45^{\circ} \mathrm{C}$ with shaking for $15 \mathrm{~min}$ and the absorbance measured at $765 \mathrm{~nm}$. A standard curve was prepared by mixing methanol solution of gallic acid $(0.2$ $\mathrm{mL} ; 0.025-0.400 \mathrm{mg} / \mathrm{mL}$ ) with $1 \mathrm{~mL}$ of $10 \% \mathrm{v} / \mathrm{v}$ FCR and sodium carbonate $(0.8 \mathrm{~mL}, 0.075 \mathrm{mg} / \mathrm{mL})$. The experiment was carried out in triplicate, and the results presented as mean values with standard deviation $( \pm \mathrm{SD})$. The TPC value was expressed as milligrams of gallic acid equivalent (GAE) per $\mathrm{g}$ of dried sample. It was calculated using the formula: $\mathrm{T}=$
$\mathrm{C} \times \mathrm{V} / \mathrm{M}$, where $\mathrm{T}$ is the TPC $(\mathrm{mg} / \mathrm{g})$ of extract, in GAE; $\mathrm{C}$ is the concentration of gallic acid from the calibration curve; $\mathrm{V}$ is the volume of the extract, $\mathrm{mL} ; \mathrm{M}$ is the dry weight $(\mathrm{g})$ of the leaf or root powder from which the extract was obtained.

2.7. Total Flavonoid Content (TFC) Assay. The concentration of flavonoids in the plant extracts was determined via aluminum colorimetric assay method [13]. Briefly, $1 \mathrm{~mL}$ of $2 \% \mathrm{w} / \mathrm{v} \mathrm{AlCl}_{3}$ was prepared in $100 \% \mathrm{v} / \mathrm{v}$ methanol added to 1 $\mathrm{mL}$ of the sample solution. A yellow colour formation after incubation at room temperature for $1 \mathrm{~h}$ was measured at $420 \mathrm{~nm}$ using an AJI-C03 UV_VIS spectrophotometer. The standard curve for TFC was obtained using quercetin as a standard drug under the same procedure described in TPC determination. The TFC was calculated using the formula: $\mathrm{T}=\mathrm{C} \times \mathrm{V} / \mathrm{M}$, where $\mathrm{T}$ is the TFC (mg/g) of extract, in $\mathrm{QE}$; $\mathrm{C}$ is the concentration of quercetin established from the calibration curve; $\mathrm{V}$ is the volume of the extract, $\mathrm{mL} ; \mathrm{M}$ is the dry weight $(\mathrm{g})$ of the leaf powder from which the extract was obtained. The TFC was present in the extracts calculated as $\mathrm{mg} / \mathrm{g}$ of quercetin equivalent $(\mathrm{QE})$.

2.8. Ferric Reducing Antioxidant Power (FRAP) Assay. The ability of plant extracts to reduce ferric $\left(\mathrm{Fe}^{3+}\right)$ to ferrous $\left(\mathrm{Fe}^{2+}\right)$ form was evaluated following the method described by Yen and Chen [14] with slight modification. A volume of 0.3 $\mathrm{mL}$ of different concentrations $(0.025-2 \mathrm{mg} / \mathrm{mL})$ from plant extract, BHT, ascorbic acid, and rutin prepared in distilled water was mixed with reacting mixture consisting of $2.5 \mathrm{~mL}$ of $0.2 \mathrm{M}$ phosphate buffer ( $\mathrm{pH} 6.6$ ) and $2.5 \mathrm{~mL}$ of $\mathrm{K}_{3} \mathrm{Fe}(\mathrm{CN})_{6}$ $(1 \% \mathrm{w} / \mathrm{v})$. The resulting mixture was incubated at $50^{\circ} \mathrm{C}$ for $20 \mathrm{~min}$ followed by addition of $2.5 \mathrm{~mL}$ of TCA $(10 \% \mathrm{w} / \mathrm{v})$. After vigorous shaking, $2.5 \mathrm{~mL}$ of the solution was mixed with $2.5 \mathrm{~mL}$ of distilled water and $0.5 \mathrm{~mL}$ of $\mathrm{FeCl}_{3}(0.1 \% \mathrm{w} / \mathrm{v})$ left incubated at room temperature for $5 \mathrm{~min}$ and then the absorbance was measured at $700 \mathrm{~nm}$ against a blank sample (without extract).

2.9. Free Radical Scavenging Activity Assays. The free radical scavenging potential of plant extracts was measured in vitro by the $1,1^{\prime}$-diphenyl-1-picrylhydrazyl (DPPH) described by Tariq et al. [15]. The assay was experimented by reacting $1.6 \mathrm{~mL}$ of $0.135 \mathrm{mM}$ DPPH dissolved in $100 \% \mathrm{v} / \mathrm{v}$ methanol with $0.4 \mathrm{~mL}$ of various concentrations $(0.078-1 \mathrm{mg} / \mathrm{mL})$ of methanol crude extracts. The reaction mixture was vortexed thoroughly and left in the dark at room temperature for $30 \mathrm{~min}$. The absorbance of the mixture was measured at $517 \mathrm{~nm}$ after $2 \mathrm{~min}$. The method of Re et al. [16] was adopted to determine ABTS radical scavenging activity of the plant extracts. The ABTS radical solution was generated by mixing two stock solutions of $7 \mathrm{mM}$ ABTS and 2.4 $\mathrm{mM}$ potassium persulphate in the same ratio and allowing the solution to react for $12 \mathrm{~h}$ at room temperature in the dark. The resulting solution was diluted with methanol to obtain an absorbance of 0.706 units at $734 \mathrm{~nm}$. A volume of $1 \mathrm{~mL}$ of various concentrations $(0.03125-1 \mathrm{mg} / \mathrm{mL})$ of the plant extracts react with $2.5 \mathrm{~mL}$ of ABTS radical solution in the dark for $15 \mathrm{~min}$ and was later measured 


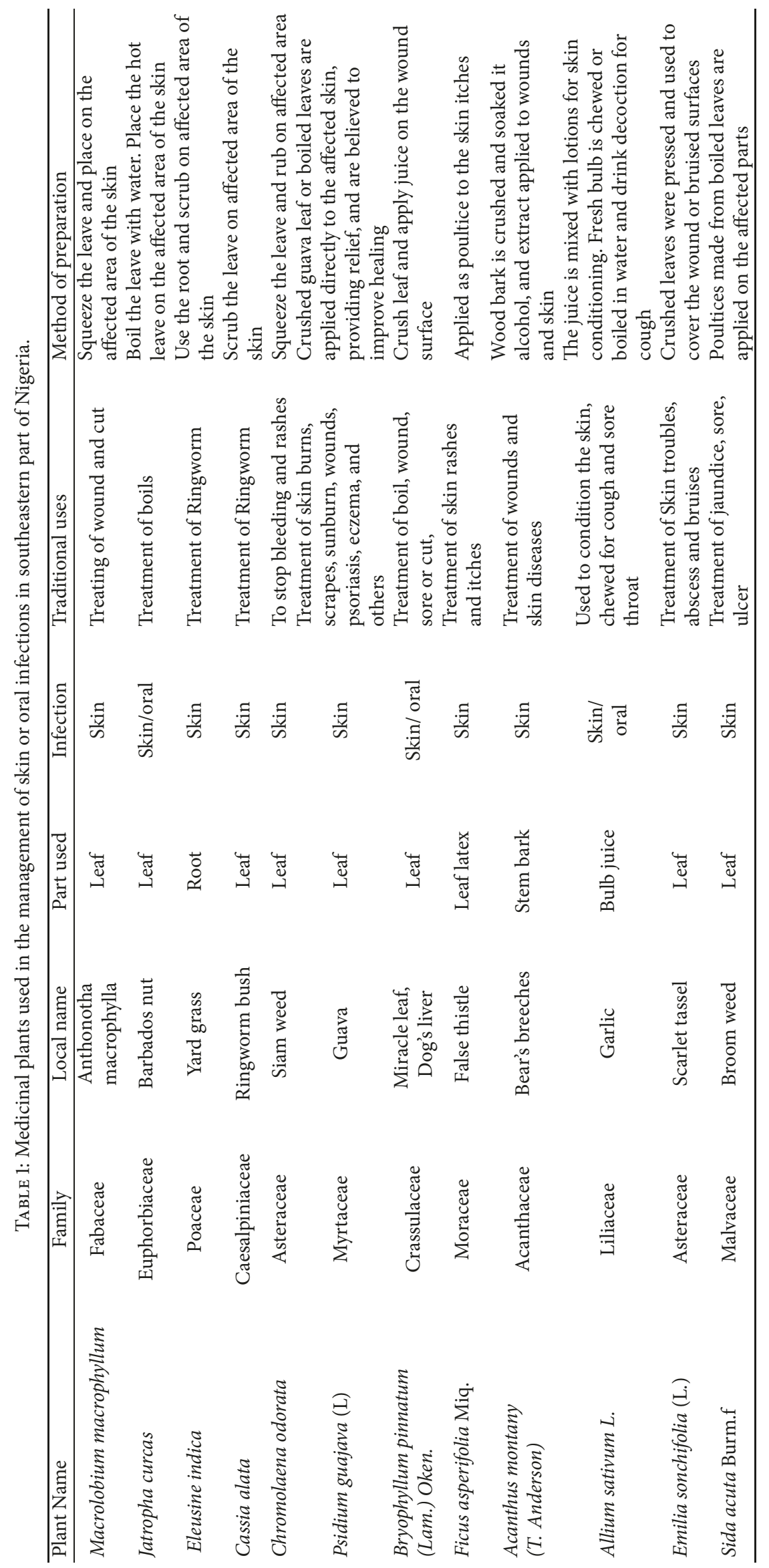




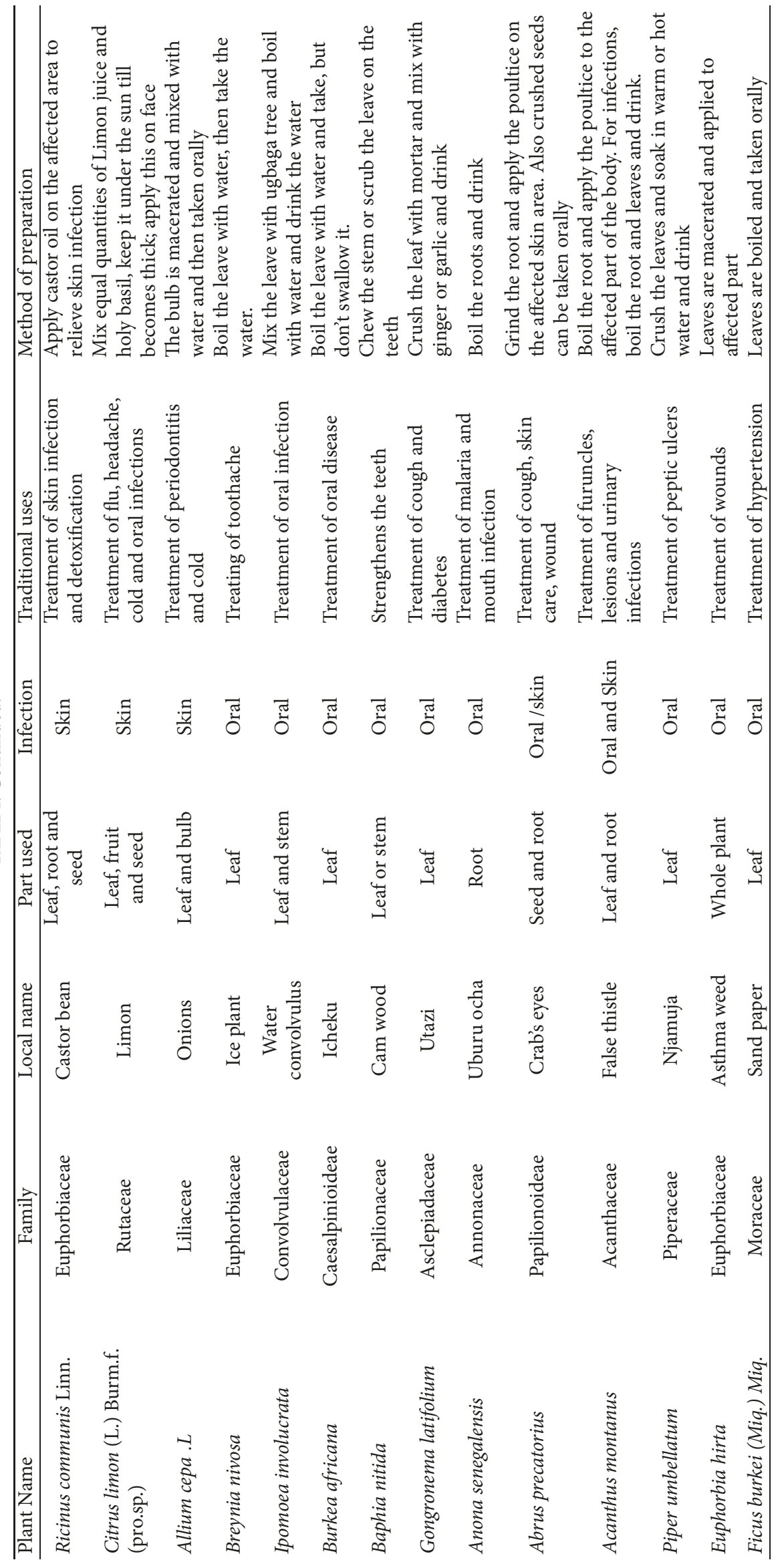




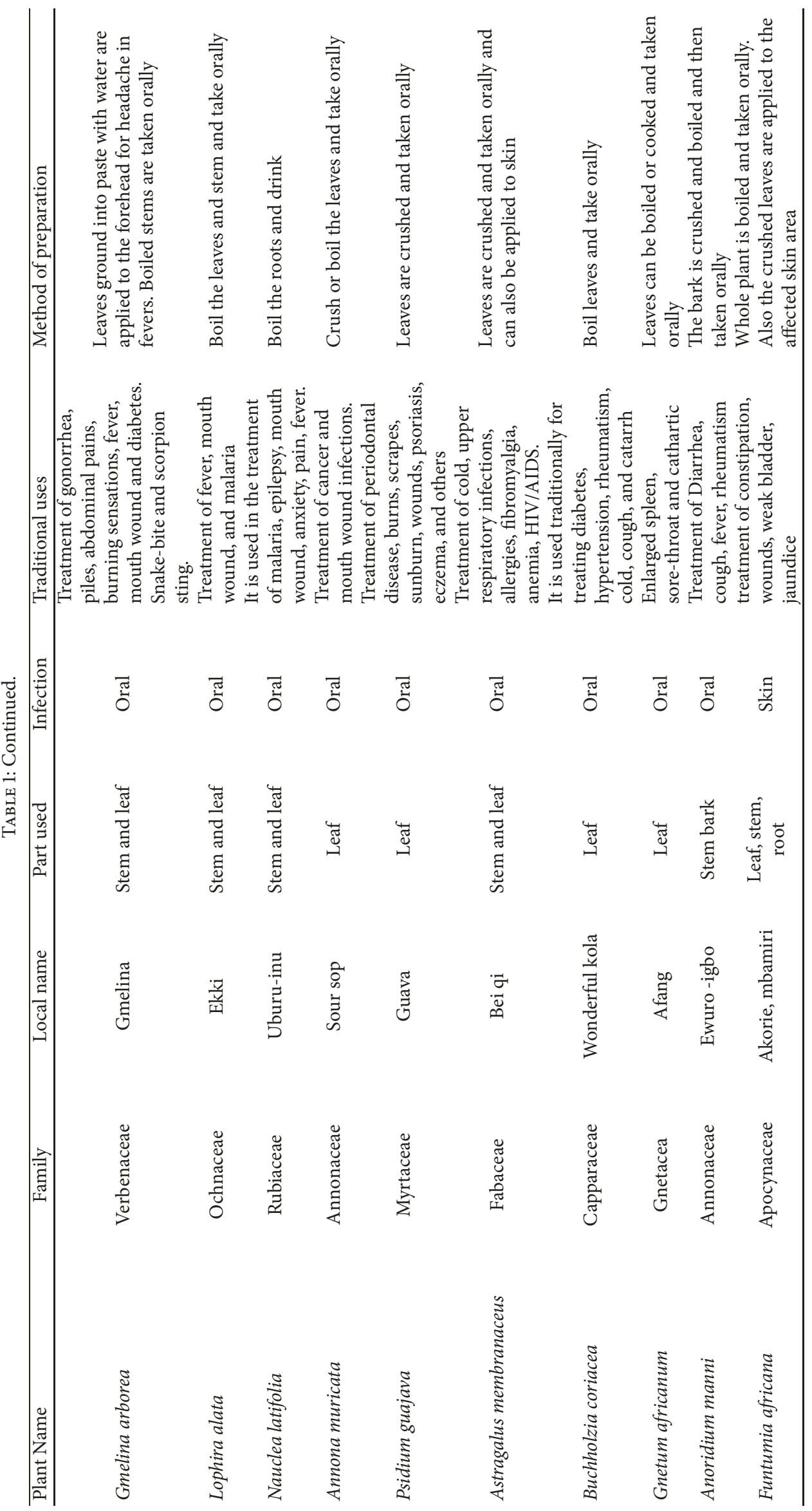




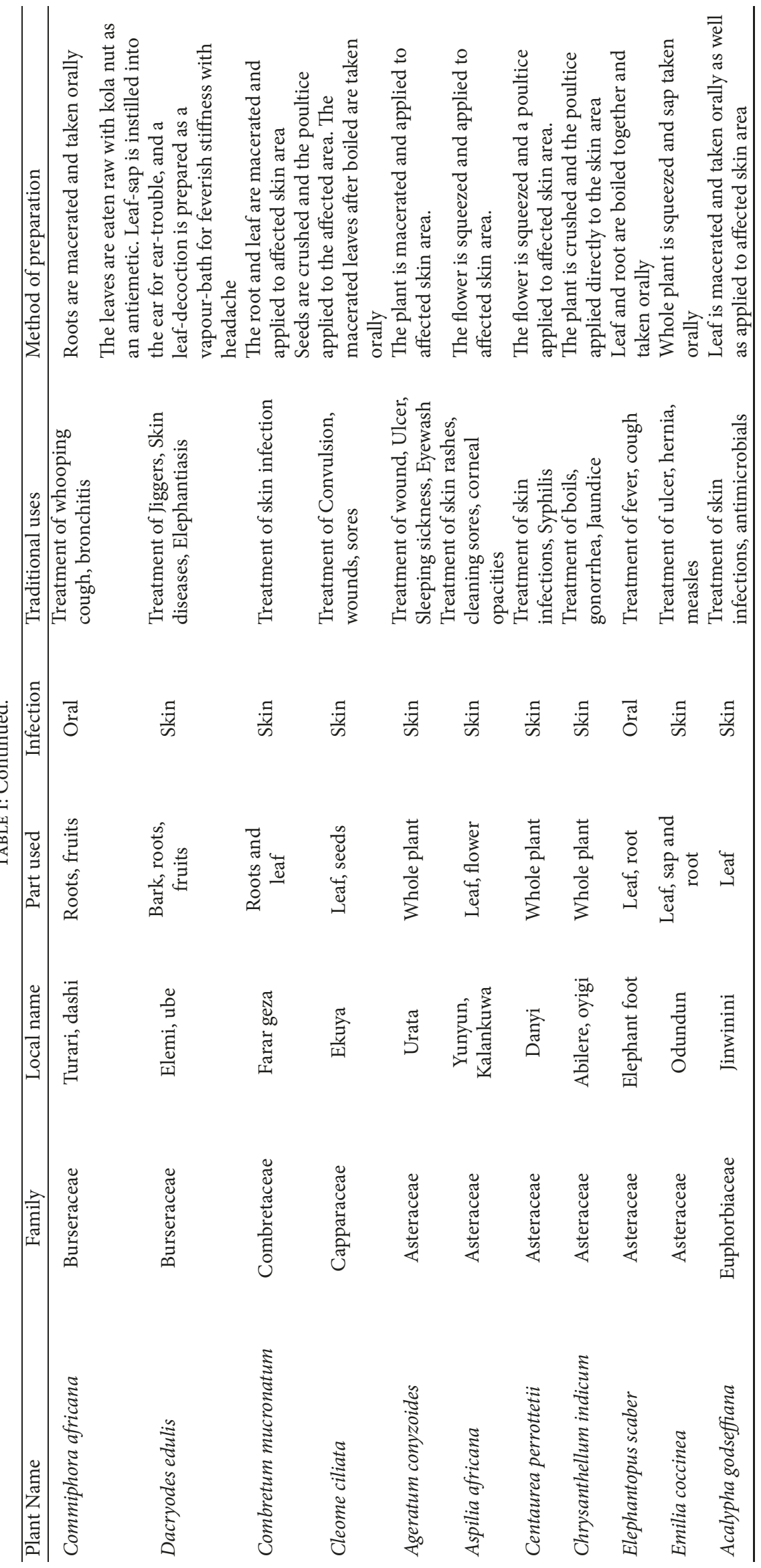




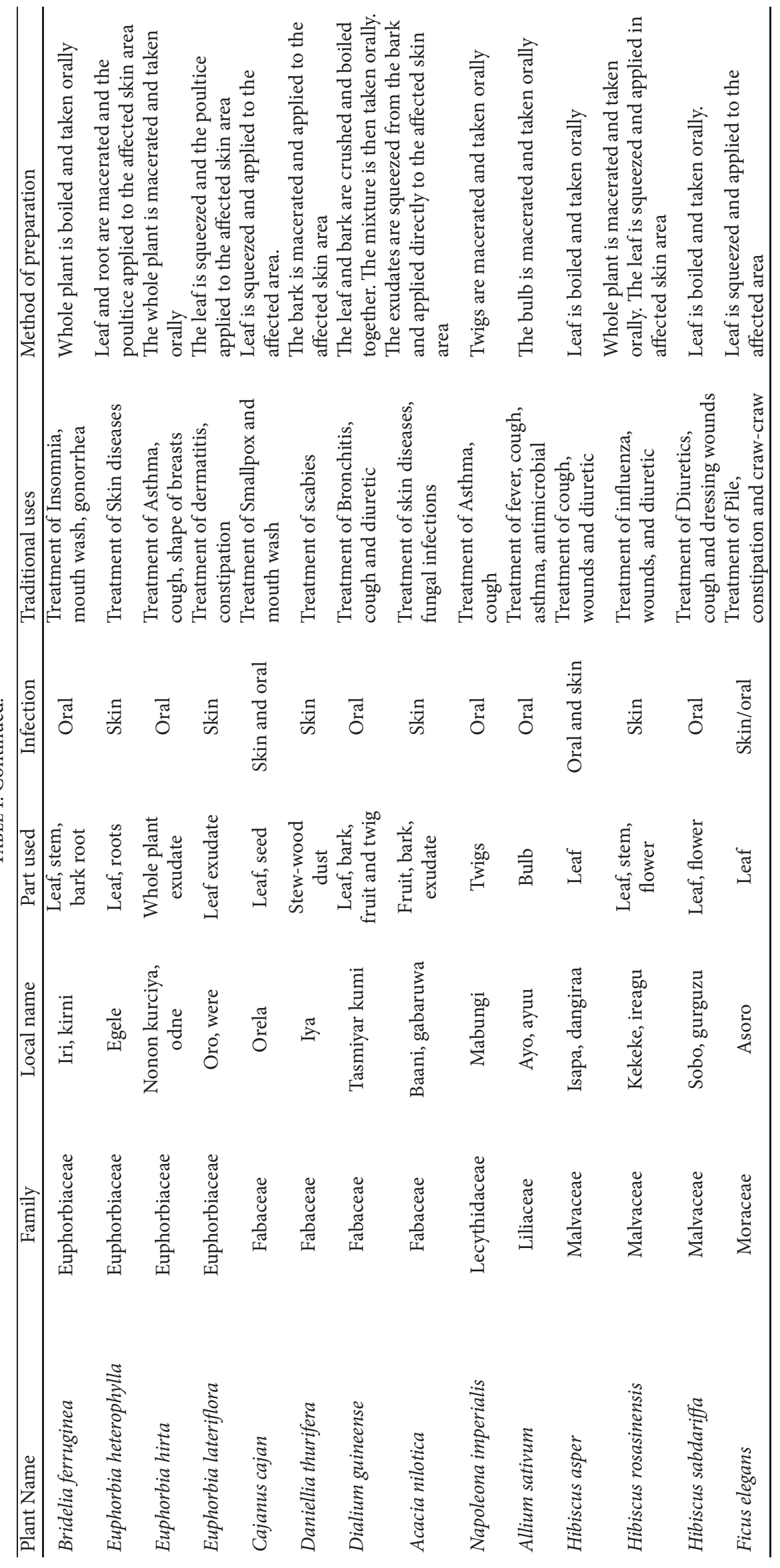


the absorbance. The percentage inhibition of DPPH or ABTS radical scavenging activity by the plant extracts was calculated as $\{($ Abscontrol - Abssample $)\} /($ Abscontrol $) \times 100$, where Abscontrol is the absorbance of DPPH or ABTS + methanol; Abssample is the absorbance of DPPH or ABTS radical + sample extract/standard. Here, the concentration of the extracts needed to decrease the absorbance of DPPH or ABTS radical by $50 \%$ was calculated. Rutin (Sigma-Aldrich, $\geq 94 \%$, HPLC grade) at the same working concentrations of the plant extracts was used as reference drug.

2.10. Bacterial Strains. All bacterial strains were cultured on nutrient agar slopes and were incubated for $24 \mathrm{~h}$ at $37^{\circ} \mathrm{C}$ before the MIC. An inoculum turbidity equivalent to a $0.5 \mathrm{McFarland}$ standard $\left(1 \times 10^{7} \mathrm{CFU} / \mathrm{mL}\right)$ was prepared in normal saline for each test organism and then diluted 1:100 in Mueller-Hinton broth just before injection of the plates. Standard strains used in the study included S. aureus and E. coli, which were a gift from Dr. EO Ekundayo (Department of Microbiology, Michael Okpara University of Agriculture), and clinically isolated strains of $K$. pneumoniae and $P$. mirabilis were gotten from Department of Microbiology, Federal Medical Centre (FMC) Umuahia, Abia State.

2.11. Antibacterial Susceptibility Using Disc Diffusion Method. The microbial growth inhibition potential of the plant extracts was determined by using the agar disc diffusion method [17]. The plant extracts were dissolved in $10 \% \mathrm{v} / \mathrm{v}$ DMSO (Merck UK Ltd) to a final concentration of $2 \mathrm{mg} / \mathrm{mL}$. The nutrient agar plate was streaked with the standardized test bacterial inoculum over the surface evenly, and $2 \mathrm{mg} / \mathrm{disc}$ of the plant extracts transferred onto sterile filter disc papers (about $6 \mathrm{~mm}$ ) containing the test compounds was placed on the agar surface in the Petri dishes. $100 \mu \mathrm{g} /$ disc of standard antibiotic ciprofloxacin was used as control and $100 \mu \mathrm{L}$ DMSO/disc served as negative control. The plates were then incubated at $37^{\circ} \mathrm{C}$ for $24 \mathrm{~h}$. Generally, the antimicrobial extracts diffuse into the agar and inhibit the growth of the test bacteria. All tests were done in duplicate and diameter zones of inhibition of growth were measured using a meter rule from the edge of each dish after the incubation period.

2.12. Minimum Inhibitory Concentration (MIC) Assays. We followed the method of Smith et al. [18] to determine the MIC of methanol crude extracts of selected botanicals against clinical isolates of bacteria associated with skin and oral infection. A volume of $100 \mathrm{~mL}$ of sterile Mueller-Hinton broth (Oxoid, Basingstoke, UK) containing $20 \mathrm{mg} / \mathrm{L}$ of $\mathrm{Ca}^{2+}$ and $10 \mathrm{mg} / \mathrm{L}$ of $\mathrm{Mg}^{2+}$ was dispensed into a 96-well microtitre plate (Nunc; $0.3 \mathrm{~mL}$ total volume per well). All antibacterial agents were dissolved in dimethyl sulphoxide (DMSO) and diluted in Mueller-Hinton broth to give a stock solution. Then, $100 \mu \mathrm{L}$ of the antibacterial agent stock solution (2000 $\mathrm{mg} / \mathrm{L}$ ) was serially diluted into each well and $100 \mathrm{~mL}$ of the bacterial inoculum added to each well to give a final concentration range of $0.024-1 \mathrm{mg} / \mathrm{L}$. All procedures were performed in duplicate and the plates were incubated for 18 $\mathrm{h}$ at $37^{\circ} \mathrm{C}$. Briefly, $20 \mathrm{~mL}$ of a $5 \mathrm{mg} / \mathrm{L}$ methanol solution of $3-$ [4,5-dimethylthiazol-2-yl]-2,5-diphenyltetrazolium bromide (MTT) (Sigma-Aldrich Ltd, South Africa) was added to each well and then incubated for $30 \mathrm{~min}$. Blue colouration indicated bacterial growth. The MIC was recorded as the lowest concentration at which no colour change was observed.

2.13. Statistical Analysis. Data analysis was done in Microsoft Excel to obtain descriptive statistics. Means values were separated by the Duncan multiple tests using SAS. The different levels of significance within the groups were analyzed using one-way analysis of variance (ANOVA). Values were considered significant at $P<0.05$.

\section{Results and Discussion}

3.1. Ethnobotanical Survey. Modern drugs are expensive and supply to a remote area may be irregular, hence resulting in overreliance of traditional methods of healing as a primary source of healthcare [19]. The rural communities of Ebem-Ohafia region of southeastern Nigeria depend on herbal remedies to meet their domestic and health needs. During our ethnobotanical survey, a total of 30 respondents including the elders, herbalists, and traditional healers were interviewed in the study area. Majority of the people (22) were aged 30-65 years, dominated by males (25), and one-third (10) had a primary school education while 15 had secondary education and others informal education. A total of 61 medicinal plant species belonging to 26 families were identified in the treatment of oral and skin diseases as shown in Table 1. Twenty-seven of them are used in the management of oral infections and twenty-six plants for the management of skin infection while eight plants are used in the management of both infections. Table 2 shows the list of family, number of the plant species used, and their percentage occurrence. The most represented plant family is the Euphorbiaceae having 18.03\% of the plant species followed by Asteraceae and Fabaceae with $11.47 \%$ each [20]. Euphorbiaceae is a large family of flowering plants with 300 genera and about 7500 species found useful in the curing of some common human diseases. Asteraceae is a large family of flowering plants having 32, 913 species and 1911 genera and has been found to possess diverse biological effects. Fabaceae is a family of cosmopolitan distribution, with approximately 730 genera and 19,400 species richness at a global level [20]. The leaves (60\%) recorded the most commonly used plant part followed by the root (16\%) and then stem bark (12\%). None of the respondents indicated any possible side effects caused by any of these plants listed in Table 1 . The most common methods of preparation include infusion, decoction, and maceration. These herbalists or traditional healers often collect the plants from the field and dry and crush them into powder form before storing in bottles to prevent patients from identifying the plants used for their treatment. Most healers refused to provide information without payment whereas others thought to provide information on the plant use is disrespect of their traditional belief. Furthermore, the majority of the plants mentioned lack scientific data to substantiate their acclaimed folkloric use. From this work, it is evident that medicinal 
TABLE 2: The list of family, number of the plant species, and their percentage occurrence.

\begin{tabular}{|c|c|c|}
\hline Family & Number of plant species & $\%$ Occurrence \\
\hline Fabaceae & 7 & 11.47 \\
\hline Euphorbiaceae & 11 & 18.03 \\
\hline Asteraceae & 7 & 11.47 \\
\hline Myrtaceae & 4 & 6.56 \\
\hline Moraceae & 3 & 4.92 \\
\hline Malvaceae & 4 & 6.56 \\
\hline Liliaceae & 2 & 3.28 \\
\hline Capparaceae & 2 & 3.28 \\
\hline Annonaceae & 3 & 4.92 \\
\hline Combretaceae & 1 & 1.64 \\
\hline Burseraceae & 2 & 3.28 \\
\hline Apocynaceae & 1 & 1.64 \\
\hline Gnetaceae & 1 & 1.64 \\
\hline Lecythidaceae & 1 & 1.64 \\
\hline Verbenaceae & 1 & 1.64 \\
\hline Ochnaceae & 1 & 1.64 \\
\hline Rubiaceae & 1 & 1.64 \\
\hline Piperaceae & 1 & 1.64 \\
\hline Acanthaceae & 2 & 3.28 \\
\hline Papilionoideae & 2 & 3.28 \\
\hline Asclepiadaceae & 1 & 1.64 \\
\hline Caesalpiniaceae & 2 & 3.28 \\
\hline Convolvulaceae & 1 & 1.64 \\
\hline Rutaceae & 1 & 1.64 \\
\hline Crassulaceae & 1 & 1.64 \\
\hline Poaceae & 1 & 1.64 \\
\hline
\end{tabular}

plants play a significant role in the primary healthcare of the people, and conservation of the indigenous knowledge of this folklore medicine is crucial for the innovations of future drug discovery and possible herbal plants trade in the region [19]. On the contrary, we observed imprecise dosage, low hygiene standards, hiding of healing methods, and lack of patients' record as a significant setback to traditional health practitioners in the region.

3.2. Thin Layer Chromatography (TLC) Profiling. Thin layer chromatography remains the most common useful technique by researchers as a quick and simple method to resolve the constituents of a crude extract followed by advanced extraction methods to purify the active ingredients. Previous studies reported that specific secondary metabolites in plant exhibit a wide range of antioxidant and antibacterial properties [21]. TLC was formed on a glass sheet coated with silica gel. After the sample is applied to the plate, a solvent system (mobile phase) is drawn up via capillary action on the TLC plate at different mobility rate depending on the chemical compositions. The separated spots with different colours were visualized by the UV light projection onto the glass sheet. The variation of coloured spots detected in the crude extracts indicates the presence of different phytochemicals that may be responsible for the pharmacological effects of selected plants use in the management of oral and skin infections as acclaimed by the traditional healers. We quantified the results by measuring the distance travelled by the plant compounds divided by the total distance travelled by the mobile phase. From Table 3, it is apparent that mobile phase 1 consisting of chloroform and ethanol in the volume ratio of 6:4 had a better separation than mobile phase II containing toluene, ethyl acetate, and acetic acid in the volume ratio of 5:4:1. The methanol extract of $\mathrm{AH}$ in both mobile phases had the highest number of three bands with $\mathrm{R}_{\mathrm{f}}$ values of $0.667,0.833$, and 0.989 for mobile phase $I$ and $R_{f}$ values of $0.381,0.648$, and 0.781 for mobile phase II. The plant extracts MM, BA, CO, JC, and CA had two bands in mobile phase I with clear separation but had single band in mobile phase II. The plant extracts having only one band in either mobile phase suggest a poor solvent system for compounds separation. The TLC profiles provide a characteristic fingerprint of these plants that may also be useful for their identification.

\subsection{Antioxidant Assays}

3.3.1. TPC and TFC. Phenolic compounds are secondary metabolites distributed in fruits, vegetables, nuts, herbs, seeds, and beverages [22]. They are excellent scavengers of free radical that has been implicated in the pathologies of various human diseases, the antioxidant activity is dependent on the structure hydrophobic benzenoid rings and hydrogenbonding potential of the phenolic hydroxyl groups. In TPC assay, a phenol in plant extracts loses a proton to form phenolate ion, which reduces Folin Ciocalteu reagent, and the resulting changes are measured spectrophotometrically at $765 \mathrm{~nm}$ [13]. The content of phenol is reported in $\mathrm{mg}$ of tannic acid equivalent (TAE)/mL of extract. As shown in Figure 1, the total phenolic contents of absolute methanol crude extract of these botanicals range from 700 to 3600 $\mathrm{mgTAE} / \mathrm{g}$. The $\mathrm{AH}$ extract had the highest concentration followed by CA, CO, MM, BNI, BA, EI, BN, and JC while the least concentration was recorded in II extract. Moreover, the Folin Ciocalteu reagent (FCR) has been used to measure other compounds such as ascorbic acid, amino acids, and sugars; hence it may not provide a concise amount of the phenolic compounds present in these plants. Flavonoids are increasingly consumed in a significant amount in daily diets worldwide due to their various health benefits to man $[23,24]$. In TFC assay, aluminum ion in the reacting mixture forms complexes with the C- 4 keto and either C- 3 or C- 5 hydroxyl, or with ortho hydroxyl groups in the $\mathrm{A}$ or $\mathrm{B}$ ring of flavonoids detected in the plant extracts [14]. As shown in Figure 2, the total flavonoid content was recorded in the plant extracts ranging from 750 to $1500 \mathrm{mgQE} / \mathrm{g}$ as extrapolated from the standard quercetin curve. The CA extract had the highest concentration followed by BNI, CO, II, AH, BN, MM, JC, and $\mathrm{BA}$ while the lowest concentration was recorded in $\mathrm{EI}$ extract. TPC is found higher than the TFC in some of the extracts supporting the fact that most flavonoids are also phenolics. According to our results, all the plant extracts are rich source of phenolic compounds. The composition of TPC and TFC registered in these plants may be difficult to 
TABLE 3: Thin layer chromatography retention factor using mobile phase CHL: ET (mobile phase I) and Tol : EA : AA (mobile phase II).

\begin{tabular}{lccc}
\hline S/N & Plant Extract & CHL: ET (6:4) & Tol: EA: AA (5:4:1) \\
\hline 1 & Baphia nitida & 1 & 0.74 \\
2 & Macrolobium macrophyllum & $0.706,0.941$ & 0.695 \\
3 & Chromolaena odorata & $0.471,0.647$ & 0.667 \\
4 & Jatropha curcas & $0.353,0.941$ & 0.648 \\
5 & Cassia alata & $0.118,0.882$ & 0.686 \\
6 & Ipomoea involucrata & 0.956 & - \\
7 & Acalypha hispida & $0.667,0.833,0.989$ & $0.381,0.648,0.781$ \\
8 & Breynia nivosa & 0.989 & 0.762 \\
9 & Burkea africana & $0.644,1$ & 0.752 \\
10 & Eleusine indica & 0.978 & 0.743 \\
\hline
\end{tabular}

CHL, chloroform; ET, ethanol; Tol, toluene; EA, ethylacetate; AA, acetic acid

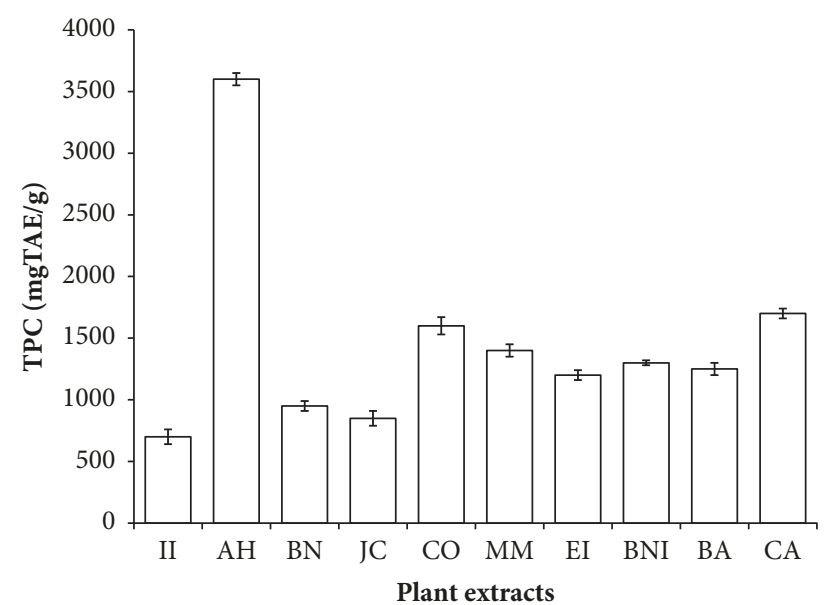

Figure 1: The total phenolic content (TPC) of selected plants used in the management of oral and skin infections in southeast Nigeria. II, Ipomoea involucrata; AH, Acalypha hispida; BN, Breynia nivosa; JC, Jatropha curcas; CO, Chromolaena odorata; MM, Macrolobium macrophyllum; EI, Eleusine indica; BNI, Baphia nitida; BA, Burkea africana; CA, Cassia alata; TAE, tannic acid equivalent.

compare with others reported elsewhere due to many factors including differences from species to species, maturity stage, plant parts, and assay methods, harvesting time, standard drugs, and geographical location.

3.3.2. Reducing Power (RP). Ferric reducing power is a global method often used to assess the capacity of antioxidants to donate either an electron or hydrogen atom to unpaired electron [25]. In reducing power assay, plant extracts exert antioxidant activities via reduction of $\mathrm{Fe}^{3+}$ ferric cyanide complex to $\mathrm{Fe}^{2+}$ (ferrous form) resulting in changing the green colour to blue and sometimes Perl's Prussian blue colour depending on the antioxidant potential [10]. As shown in Figure 3, the reducing power of the methanol crude extracts and the standard gallic acid, rutin, and ascorbic acid increased with increase in concentration. Higher absorbance at $700 \mathrm{~nm}$ can be read after potassium ferricyanide reaction with ferric chloride. At $1000 \mu \mathrm{g} / \mathrm{mL}$, the extracts from $\mathrm{AH}$,

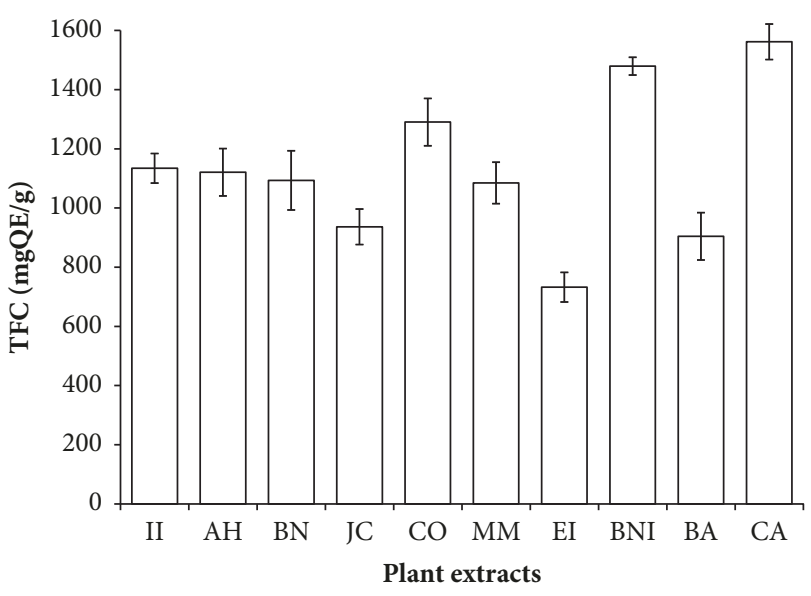

Figure 2: The total flavonoid content (TFC) of selected plants used in the management of oral and skin infections in southeast Nigeria. II, Ipomoea involucrata; AH, Acalypha hispida; BN, Breynia nivosa; JC, Jatropha curcas; CO, Chromolaena odorata; MM, Macrolobium macrophyllum; EI, Eleusine indica; BNI, Baphia nitida; BA, Burkea africana; CA, Cassia alata; QE, Quercetin equivalent.

BNI, MM, CA, BA, EI, and BN had absorbance value of 2.70, $0.86,0.73,0.55,0.36,0.27$, and 0.27 , respectively, while that of $\mathrm{AH}$ is higher than the standard rutin (2.54) but comparable well with gallic acid (2.75) and ascorbic acid (2.69). EI and $\mathrm{BN}$ extracts had a similar trend of ferric reducing power though significantly lower as compared with the standard drugs. AH extract exhibits remarkable antioxidant capacity (RP) correlating with its richness in phenolic and flavonoid contents. It is reasonable to suggest that methanol selectively extracts antioxidant principles from these botanicals based on their polarities and chemical structures which are reflected in plant extracts with high TFC and TPC having minimal RP [26]. We have shown that some plant extracts, in particular, $\mathrm{AH}, \mathrm{BNI}, \mathrm{MM}$, and CA extracts, may serve as an excellent candidate to minimize skin and oral infections caused by oxidative stress as a result of imbalance of free radicals generation and natural antioxidants in the saliva or wound area. According to our results, the increasing RP of the plant extracts correlates with their TPC and TFC. This study, at least 


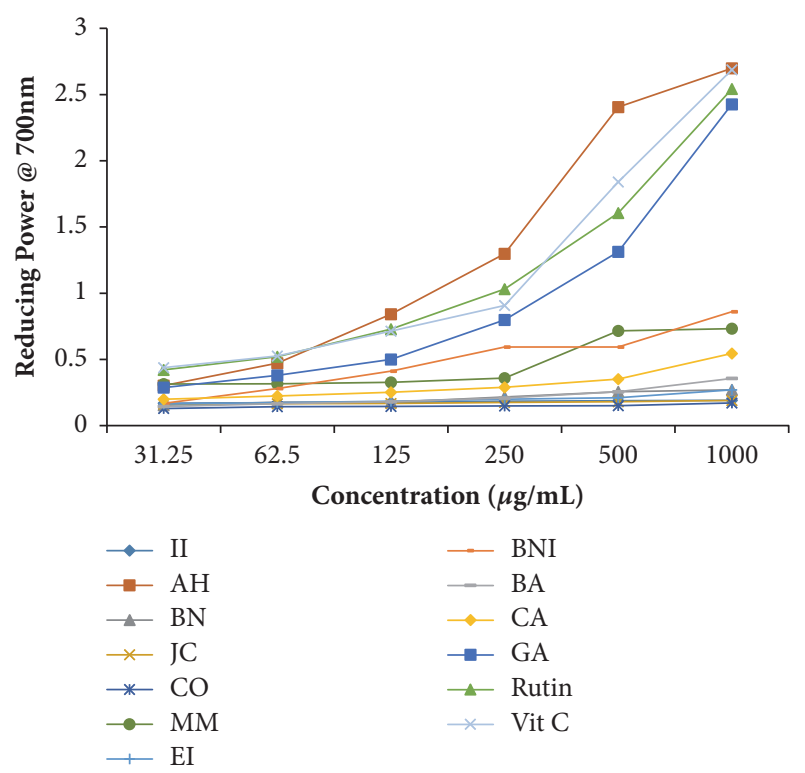

FIGURE 3: The ferric reducing antioxidative capacity of selected plant extracts used in the management of oral and skin infections in southeast folklore medicine of Nigeria. II, Ipomoea involucrata; AH, Acalypha hispida; BN, Breynia nivosa; JC, Jatropha curcas; CO, Chromolaena odorata; MM, Macrolobium macrophyllum; EI, Eleusine indica; BNI, Baphia nitida; BA, Burkea africana; CA, Cassia alata; GA, gallic acid; Vit C, vitamin C (standard antioxidants).

in part, lends credence to the ethno-therapeutic use of some plant as natural antioxidant in the management of skin or oral infections in the study area.

3.3.3. FRSA of Plant Extracts. Skin and oral cavity exposed to an array of oxidants such as smokes from cigarettes, chemicals, UV light, nicotine, and alcohol that are directly or indirectly leading to the production of reactive oxygen species (ROS) are known to be responsible for some common human diseases [27]. These free radicals in particular hydroxyl and superoxide anions are highly reactive molecules derived from the metabolism of oxygen. Although they play an important role in the biochemical, immunological, and physiological processes, it could be deleterious to vital organs if excessively accumulated in the human body [28]. Food and pharmaceutical industries discovered that medicinal plants containing phenol and flavonoid compounds are essential in the development of novel drugs against stress-induced diseases [28]. In the present investigation, the concentration $\left(\mathrm{IC}_{50}\right)$ at which $50 \%$ of free radical scavenged was calculated and extrapolated from the plot of percentage inhibition versus plant extract concentration. The herbal drugs exhibited robust DPPH radical scavenging activity in a concentrationdependent manner having $\mathrm{IC}_{50}$ ranging from 20.25 to 710 $\mu \mathrm{g} / \mathrm{mL}$. As shown in Figure 4, MM, BA, EI, JC, AH, BNI, and CA extracts had a potent DPPH radical scavenging activity corresponding to their TPC, TFC, and RP. The plant extracts scavenged ABTS radical by the decrease in its absorbance at $734 \mathrm{~nm}$. All the plant extracts exhibited strong ABTS radical scavenging capacities in the following

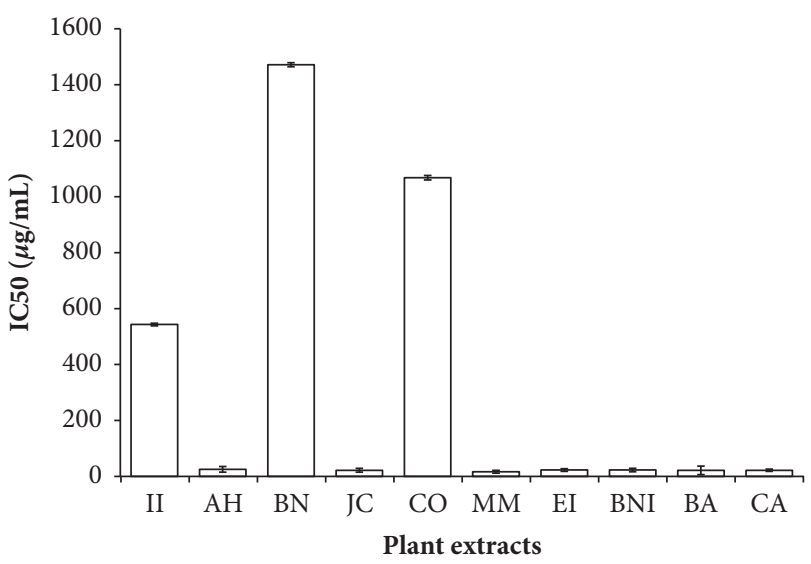

FIGURE 4: DPPH free radical scavenging activity of selected plant extracts used in the management of oral and skin infections in southeast folklore medicine of Nigeria. II, Ipomoea involucrata; AH, Acalypha hispida; BN, Breynia nivosa; JC, Jatropha curcas; CO, Chromolaena odorata; MM, Macrolobium macrophyllum; EI, Eleusine indica; BNI, Baphia nitida; BA, Burkea africana; CA, Cassia alata.

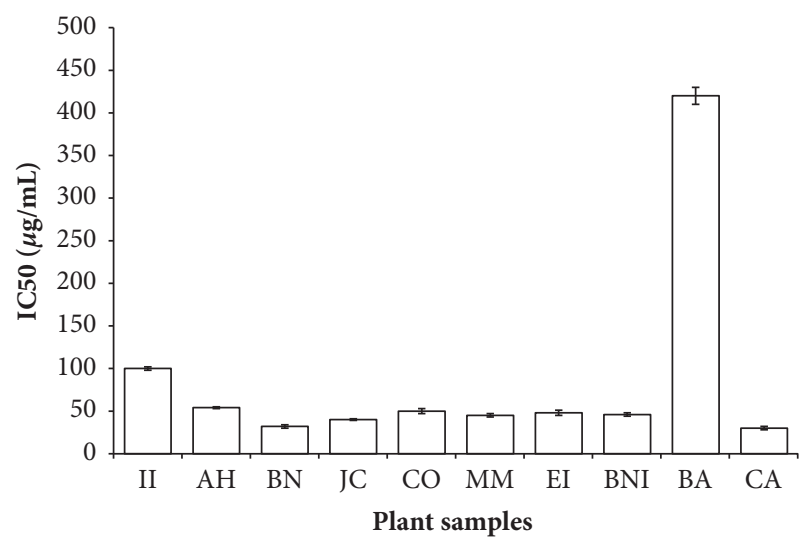

FIGURE 5: ABTS free radical scavenging activity of selected plant extracts used in the management of oral and skin infections in southeast folklore medicine of Nigeria. II, Ipomoea involucrata; AH, Acalypha hispida; BN, Breynia nivosa; JC, Jatropha curcas; CO, Chromolaena odorata; MM, Macrolobium macrophyllum; EI, Eleusine indica; BNI, Baphia nitida; BA, Burkea africana; CA, Cassia alata.

order: $\mathrm{BN}>\mathrm{JC}>\mathrm{CA}>\mathrm{MM}>\mathrm{BNI}>\mathrm{EI}>\mathrm{CO}>\mathrm{AH}>$ II $>$ BA having IC $_{50}$ values ranging from 25 to $400 \mu \mathrm{g} / \mathrm{mL}$ (Figure 5). DPPH and ABTS radical scavenging activities of these herbal remedies displayed a positive correlation with the working concentrations. It is obvious that most of the plant extracts tested in this work possess the ability to quench the free radicals generation via electron or proton donation demonstrated by the termination of radical chain reaction [28]. Although both DPPH and ABTS radicals are electrontransfer based methods, however, it is apparent that ABTS method seems to be more sensitive than DPPH radical assay, possibly due to their solubility and diffusivity as shown in the $\mathrm{IC}_{50}$ values [10]. It is worth noting that $\mathrm{BA}$ extract with strong DPPH radical scavenging effect had a moderate ABTS 
TABLE 4: Zone of bacterial inhibition by the selected plant extracts use in the management of oral and skin infections.

\begin{tabular}{|c|c|c|c|c|c|}
\hline \multicolumn{6}{|c|}{ Diameter of inhibition $(\mathrm{mm})$} \\
\hline $\mathrm{S} / \mathrm{N}$ & Plant samples & K. pneumoniae & P. mirabilis & S. aureus & E. coli \\
\hline 1 & Cassia alata & $15 \pm 1.41$ & $9 \pm 0.42$ & $15 \pm 0.83$ & $13 \pm 0.80$ \\
\hline 2 & Breynia nivosa & $8 \pm 0.52$ & $17 \pm 1.00$ & $8 \pm 0.08$ & $15 \pm 1.02$ \\
\hline 3 & Burkea africana & NI & $11 \pm 0.84$ & $13 \pm 0.72$ & NI \\
\hline 4 & Baphia nitida & $8 \pm 0.50$ & $13 \pm 1.22$ & $8 \pm 0.51$ & NI \\
\hline 5 & Ipomoea involucrata & $8 \pm 0.52$ & NI & $8 \pm 0.50$ & $13 \pm 0.52$ \\
\hline 6 & Jatropha curcas & NI & $9 \pm 0.30$ & $9 \pm 0.62$ & $13 \pm 0.72$ \\
\hline 7 & Acalypha hispida & $21 \pm 1.63$ & NI & $11 \pm 0.09$ & $17 \pm 1.32$ \\
\hline 8 & Chromolaena odorata & $8 \pm 0.42$ & $8 \pm 0.35$ & $9 \pm 0.09$ & $15 \pm 1.20$ \\
\hline 9 & Eleusine indica & $8 \pm 0.42$ & $8 \pm 0.35$ & NI & $17 \pm 1.00$ \\
\hline 10 & Macrolobium macrophyllum & NI & NI & $8 \pm 0.04$ & $15 \pm 1.23$ \\
\hline 11 & Ciprofloxacin & - & - & $\leq 16(\mathrm{R}) ; \geq 17(\mathrm{~S})$ & $\leq 16(\mathrm{R}) ; \geq 20(\mathrm{~S})$ \\
\hline
\end{tabular}

NI indicates no zone of inhibition; S, sensitive; $R$, resistance

radical scavenging capacity which can be explained by the partial ionization of the extract in the test medium [29]. Since ROS promotes tissue damage and epithelial inflammation via exposure to sunlight, radiation, or smoke as a result the antioxidant capacity demonstrated in this work may support the traditional use of these plants against the influence of inflammatory markers and oxidants in the skin and oral cavity [29]. Based on the results of the three antioxidant assays, it is obvious that $\mathrm{MM}, \mathrm{AH}, \mathrm{BNI}, \mathrm{EI}$, and CA extracts had the best FRSA indicating their importance in converting free radicals into more stable products and then terminate the free radical chain reaction. Our study showed that the methanol crude extracts from these plants could protect against free radical damage in the mouth such as human gingival, periodontal tissues, and certain skin infections [5].

3.3.4. Antibacterial Activity of Plant Extracts. Pathogenic bacteria such as Staphylococcus aureus, Escherichia coli, Klebsiella pneumoniae, and Proteus mirabilis play a significant role as the primary cause of skin and oral infections [30]. Staphylococcus aureus is a part of normal skin known to be the most problematic in the cause of skin infections as a result of their resistance mechanisms to first-line antibiotics [30]. Although the presence of this organism as a resident oral floral is controversial, nonetheless, MSSA and MRSA have been isolated from oral rinse and tongue swab in patients with oral infections [31]. Escherichia coli are Gramnegative bacteria known to be notorious for their resistant mechanisms towards the existing arsenal of antibiotics. Oral infections such as edematous and erythematous and skin infections like omphalitis, surgical site infections, burn, necrotizing fasciitis, and cellulitis at all age groups are associated with enterobacterium E. coli [32]. Klebsiella pneumoniae is a Gram-negative, encapsulated, facultative anaerobic, and rod-shaped bacterium found in the normal flora of the mouth, skin, and intestines. This bacterium is responsible for the prolonged surgical wound, biliary tract wound, and urinary tract infections and it could pose a serious health risk when resistant strains invade the throat, mouth, or intestines [33]. Villegas et al. [34] detected a CTX-M-12 $\beta$ lactamase producing $K$. pneumoniae new plasmid-mediated ESBLs highly resistant to ceftazidime from a patient with hospital-acquired wound infection. Proteus mirabilis is one of the most common enterobacteria after E. coli identified as Gram-negative, motile, and rod-shaped bacterium. It is found in clinical specimen implicated in the skin, respiratory tract, and bacteraemia as well as burns, wounds, and urinary tract infections [35]. All these pathogenic multidrug-resistance bacteria are causative agent in a periodontal, lips ulcer, white sponge nevus, and skin infections [36].

3.3.5. Susceptibility Test and MIC Determination. The result of disc diffusion assay showed the diameter of inhibition of bacteria growth classified as $\leq 15$ (resistant) and $\geq 16$ (susceptible) according to CLSI guideline [37]. As shown in Table 4, K. pneumoniae and E. coli are more susceptible to the treatment of Acalypha hispida (AH) having a zone of inhibition (ZI) 21 and $17 \mathrm{~mm}$, respectively. BN and EI extracts inhibit the growth of $P$. mirabilis and E. coli having the same zone of inhibition $17 \mathrm{~mm}$ corresponding to the report of $\mathrm{Al}$ Zubairi et al. [38]. The data obtained for the methanol crude extracts from $\mathrm{AH}, \mathrm{BN}$, and $\mathrm{EI}$ show their selective inhibition of the test bacteria growth. The plant extracts with ZI above $13 \mathrm{~mm}$ against our panel of bacterial strains were selected for MIC determination. Here the methanol crude extracts exhibit MIC values of 256 to $>512 \mu \mathrm{g} / \mathrm{mL}$ against the test bacterial strains but were less active as compared to the standard ciprofloxacin $0.03-0.06 \mu \mathrm{g} / \mathrm{mL}$ (Table 5). Ciprofloxacin is an active broad-spectrum antibiotic use in the treatment of urinary tract infections, prostatitis, and acute cystitis via interfering with bacterial DNA replication and transcription through inhibition of DNA gyrase or topoisomerase [39]. All the plant extracts demonstrated a mild to weak antibacterial activity based on the classification of Rios and Recio [40] who considered antibacterial activity of the crude plant extract significant $(\mathrm{MIC}<100 \mu \mathrm{g} / \mathrm{mL})$, moderate $(100<\mathrm{MIC}=512$ $\mu \mathrm{g} / \mathrm{mL}$ ), or weak (MIC > $512 \mu \mathrm{g} / \mathrm{mL}$ ). The herbal remedies showed moderate inhibition of bacterial growth except for $K$. 
TABLE 5: Minimum inhibitory concentration (MIC) of selected medicinal plants against bacterial strains associated with oral and skin infections.

\begin{tabular}{lcccc}
\hline Plants & SA & KP & $\begin{array}{c}\text { PM } \\
\text { MIC }(\mu \mathrm{g} / \mathrm{mL})\end{array}$ & EC \\
\hline Acalypha hispida & 512 & 256 & $>512$ & 512 \\
Cassia alata & 512 & 256 & 256 & 256 \\
Breynia nivosa & 256 & $>512$ & 256 & 512 \\
Eleusine indica & 256 & 512 & 256 & 512 \\
Chromolaena odorata & 512 & 256 & 256 & 256 \\
Ciprofloxacin & 0.03 & 0.03 & 0.03 & 0.03 \\
\hline
\end{tabular}

SA, S. aureus; KP, K. pneumoniae; PM, P. mirabilis; EC, E. coli.

pneumoniae and $P$. mirabilis towards $\mathrm{BN}$ and $\mathrm{AH}$ extracts, respectively. $\mathrm{BN}$ and $\mathrm{EI}$ extracts were more active against $S$. aureus and P. mirabilis; CA and CO extracts were more active against all the test bacterial strains except $S$. aureus. Previous work reported by Amadi et al. [41] confirmed the weak antibacterial activity exhibited by $\mathrm{BN}$ extract against K. pneumoniae. The antibacterial activity demonstrated by $\mathrm{AH}$ extract against our panel of bacterial strains contradicts that of Aboaba and Yeye [42] who reported MIC value of $100 \mathrm{mg} / \mathrm{mL}$ against E. coli, S. aureus, and K. pneumoniae. It is interesting to note that K. pneumoniae, E. coli, and $P$. mirabilis that confer resistance to the extended spectrum cephalosporin and penicillin [43] are more susceptible to the treatment with $\mathrm{CA}$ and $\mathrm{CO}$ extracts. Furthermore, the observed antibacterial activity exhibited by EI, CA, and CO extracts against the superbugs of modern day healthcare [38] is worth noting which may perhaps attribute to a wide variety of secondary metabolites especially phenolics and flavonoids that have been reported with potent antimicrobial properties [44]. Among the three extracts, Eleusine indica has $\mathrm{IC}_{50}>$ $30 \mu \mathrm{g} / \mathrm{mL}$ towards MCF-7, HT-29, and CEM-SS human cancer cell lines suggesting that continued exposure to this herbal remedy may alter human organs [38]. The probable mechanism of action of these plants is not known but it could be attributed to the leakage of the cell wall or alteration in the membrane permeability or inhibition of enzyme gyrase, DNA synthesis, and protein synthesis [45]. Further researches are needed to identify the active ingredients, curare effect, and the molecular mechanisms of these plants.

\section{Conclusion}

The results of this study, therefore, at least in part provide scientific evidence for the traditional use of these medicinal plants in ethnomedicine by the dwellers of Ebem-Ohafia communities in the treatment of skin and oral infections. The free radicals scavenging activity, moderate to high TPC, TFC, and the mild antibacterial properties demonstrated by certain plant extracts are worth harnessing for proper evaluation and integration into the primary healthcare system. Further fractionation to identify the single compound responsible for the observed activities is highly recommended. Encouragingly, $\mathrm{BN}, \mathrm{CA}, \mathrm{CO}$, and $\mathrm{AH}$ extracts with potent antioxidant and antibacterial properties did not exhibit any significant toxic effect as reported by other researchers and thus substantiate its safe use as complementary and alternative therapy for the treatment or prevention of human diseases.

\section{Data Availability}

The data used to support the findings of this study are available from the corresponding author upon request.

\section{Conflicts of Interest}

No potential conflicts of interest were reported by the authors.

\section{Acknowledgments}

The authors thank the National Research Foundation (NRF), South Africa Agency for Science and Technology Advancement for their financial support.

\section{References}

[1] World Health Organization, “Oral health," Fact sheets 318, 2012, http://www.who.int/mediacentre/factsheets/fs318/en/index.html.

[2] F. E. Dewhirst, T. Chen, J. Izard et al., "The human oral microbiome," Journal of Bacteriology, vol. 192, no. 19, pp. 50025017, 2010.

[3] M. L. Falsetta, M. I. Klein, P. M. Colonne et al., "Symbiotic relationship between Streptococcus mutans and Candida albicans synergizes virulence of plaque biofilms in vivo," Infection and Immunity, vol. 82, no. 5, pp. 1968-1981, 2014.

[4] A. Shinde, J. Ganu, and P. Naik, "Effect of Free Radicals \& Antioxidants on Oxidative Stress: A Review," Journal of Dental and Allied Sciences, vol. 1, no. 2, p. 63, 2012.

[5] O. Hershkovich, I. Shafat, and R. M. Nagler, "Age-related changes in salivary antioxidant profile: possible implications for oral cancer," Journals of Gerontology, Series A: Biological Sciences and Medical Sciences, vol. 62, no. 4, pp. 361-366, 2007.

[6] S. Jagtap, S. Yavankar, K. Pardesi, and B. Chopade, "Production of bioemulsifier by Acinetobactersp. from healthy human skin of tribal population," Indian Journal of Experimental Biology, vol. 48, pp. 70-76, 2010.

[7] D. H. Limoli, A. B. Rockel, K. M. Host et al., "Cationic Antimicrobial Peptides Promote Microbial Mutagenesis and Pathoadaptation in Chronic Infections," PLoS Pathogens, vol. 10, no. 4, Article ID e1004083, 2014.

[8] A. Al-Ahmad, H. Ameen, K. Pelz et al., "Antibiotic resistance and capacity for biofilm formation of different bacteria isolated from endodontic infections associated with root-filled teeth," Journal of Endodontics, vol. 40, no. 2, pp. 223-230, 2014.

[9] F. A. Badria and O. A. Zidan, "Natural products for dental caries prevention," Journal of Medicinal Food, vol. 7, no. 3, pp. 381-384, 2004.

[10] S. O. Oyedemi, B. O. Oyedemi, I. I. Ijeh, P. E. Ohanyerem, R. M. Coopoosamy, and O. A. Aiyegoro, "Alpha-amylase inhibition and antioxidative capacity of some antidiabetic plants used by the traditional healers in Southeastern Nigeria," The Scientific World Journal, vol. 2017, Article ID 3592491, 11 pages, 2017.

[11] T. Vogt, "Phenylpropanoid biosynthesis," Molecular Plant, vol. 3, no. 1, pp. 2-20, 2010. 
[12] H. Ghaffari, B. J. Ghassam, S. C. Nayaka, K. Ramachandra Kini, and H. S. Prakash, "Antioxidant and neuroprotective activities of Hyptis suaveolens (L.) Poit. against oxidative stress-induced neurotoxicity," Cellular and Molecular Neurobiology, vol. 34, no. 3, pp. 323-331, 2014.

[13] C. Chang, M. Yang, H. Wen, and J. Chern, "Estimation of total flavonoid content in propolis by two complementary colometric methods," Journal of Food and Drug Analysis, vol. 10, no. 3, pp. 178-182, 2002.

[14] G. C. Yen and H. Y. Chen, "Antioxidant activity of various tea extracts in relation to their antimutagenicity," Journal of Agricultural and Food Chemistry, vol. 43, no. 1, pp. 27-32, 1995.

[15] A. Tariq, M. Athar, J. Ara, V. Sultana, S. Ehteshamul-Haque, and M. Ahmad, "Biochemical evaluation of antioxidant activity in extracts and polysaccharide fractions of seaweeds," Global Journal of Environmental Science Management, vol. 1, no. 1, pp. 47-62, 2015.

[16] R. Re, N. Pellegrini, A. Proteggente, A. Pannala, M. Yang, and C. Rice-Evans, "Antioxidant activity applying an improved ABTS radical cation decolorization assay," Free Radical Biology \& Medicine, vol. 26, no. 9-10, pp. 1231-1237, 1999.

[17] National Committee for Clinical Laboratory Standards, "Performance Standards for antimicrobial susceptibility testing," 8th Informational Supplement M100 S12, National Committee for Clinical Laboratory Standards, Villanova, Pa, USA, 2002.

[18] E. E. Smith, E. Williamson, M. Zloh, and S. Gibbons, "Isopimaric acid from Pinus nigra shows activity against multidrugresistant and EMRSA strains of Staphylococcus aureus," Phytotherapy Research, vol. 19, no. 6, pp. 538-542, 2005.

[19] N. R. Farnsworth, "Ethnopharmacology and drug development," Ciba Foundation Symposium, vol. 185, pp. 42-59, 2007.

[20] W. S. Judd, C. S. Campbell, E. A. Kellogg, P. F. Stevens, and M. J. Donoghue, Plant Systematics: A Phylogenetic Approach, Sinauer Associates, Sunderland, Mass, USA, 2002.

[21] M. Wink, Functions of Plant Secondary Metabolites and their Exploitation in Biotechnology, vol. 39 of Annual Plant Reviews, Wiley-Blackwell, London, UK, 2010.

[22] V. Cheynier, "Polyphenols in foods are more complex than often thought," The American Journal of Clinical Nutrition, vol. 81, supplement 1, pp. 223S-229S, 2005.

[23] P. C. H. Hollman and M. B. Katan, "Dietary flavonoids: Intake, health effects and bioavailability," Food and Chemical Toxicology, vol. 37, no. 9-10, pp. 937-942, 1999.

[24] G. P. Hubbard, S. Wolffram, J. A. Lovegrove, and J. M. Gibbins, "Ingestion of quercetin inhibits platelet aggregation and essential components of the collagen-stimulated platelet activation pathway in humans," Journal of Thrombosis and Haemostasis, vol. 2, no. 12, pp. 2138-2145, 2004.

[25] M.-C. Kou, S.-Y. Chiou, C.-Y. Weng, L. Wang, C.-T. Ho, and M.-J. Wu, "Curcuminoids distinctly exhibit antioxidant activities and regulate expression of scavenger receptors and heme oxygenase-1," Molecular Nutrition \& Food Research, vol. 57, no. 9, pp. 1598-1610, 2013.

[26] M.-Y. Juan and C.-C. Chou, "Enhancement of antioxidant activity, total phenolic and flavonoid content of black soybeans by solid state fermentation with Bacillus subtilis BCRC 14715," Food Microbiology, vol. 27, no. 5, pp. 586-591, 2010.

[27] S. O. Oyedemi and A. J. Afolayan, "In vitro and in vivo antioxidant activity of aqueous leaves extract of Leonotis leonurus (L.) R. Br," International Journal of Pharmacology, vol. 7, no. 2, pp. 248-256, 2011.
[28] A. Temraz and W. H. El-Tantawy, "Characterization of antioxidant activity of extract from Artemisia vulgaris," Pakistan Journal of Pharmaceutical Sciences, vol. 21, no. 4, pp. 321-326, 2008.

[29] I. Fridovich, "Fundamental aspects of reactive oxygen species, or what's the matter with oxygen?" Annals of the New York Academy of Sciences, vol. 893, no. 22, pp. 13-18, 1999.

[30] D. J. Wilson, R. N. Gonzalez, and H. H. Das, "Bovine mastitis pathogens in New York and Pennsylvania: prevalence and effects on somatic cell count and milk production," Journal of Dairy Science, vol. 80, no. 10, pp. 2592-2598, 1997.

[31] A. J. Smith, M. S. Jackson, and J. Bagg, "The ecology of staphylococci in the oral cavity: a review," Journal of Medical Microbiology, vol. 50, no. 11, pp. 940-946, 2001.

[32] G. J. Moet, R. N. Jones, D. J. Biedenbach, M. G. Stilwell, and T. R. Fritsche, "Contemporary causes of skin and soft tissue infections in North America, Latin America, and Europe: report from the SENTRY antimicrobial surveillance program (1998-2004)," Diagnostic Microbiological Infectious Diseases, vol. 57, no. 1, pp. 7-13, 2007.

[33] K. J. Ryan and C. G. Ray, Sharris Medicinal Microbiology, McGraw Hill, New York, NY, USA, 4th edition, 2004.

[34] M. V. Villegas, A. Correa, F. Perez et al., "CTX-M-12 $\beta$-lactamase in a Klebsiella pneumoniae clinical isolate in Colombia," Antimicrobial Agents and Chemotherapy, vol. 48, no. 2, pp. 629-631, 2004.

[35] R. Tibbetts, J. G. Frye, J. Marschall, D. Warren, and W. Dunne, "Detection of KPC-2 in a clinical isolate of Proteus mirabilis and first reported description of carbapenemase resistance caused by a KPC $\beta$-lactamase in P. mirabilis," Journal of Clinical Microbiology, vol. 46, no. 9, pp. 3080-3083, 2008.

[36] S. M. Jacobsen, D. J. Stickler, H. L. T. Mobley, and M. E. Shirtliff, "Complicated catheter-associated urinary tract infections due to Escherichia coli and Proteus mirabilis," Clinical Microbiology Reviews, vol. 21, no. 1, pp. 26-59, 2008.

[37] Clinical and Laboratory Standards Institute, "Methods for dilution antimicrobial susceptibility tests for bacteria that grow aerobically; approved standard," CLSI document M7-A7, Clinical and Laboratory Standards Institute, Wayne, Pa, USA, 2006.

[38] A. S. Al-Zubairi, A. B. Abdul, S. I. Abdelwahab, C. Y. Peng, S. Mohan, and M. M. Elhassan, "Eleucine indica possesses antioxidant, antibacterial and cytotoxic properties," Evidence-Based Complementary and Alternative Medicine, vol. 2011, Article ID 965370, 6 pages, 2011.

[39] Y. A. Al-Soud and N. A. Al-Masoudi, "A new class of dihaloquinolones bearing $\mathrm{N}^{\prime}$ - aldehydoglycosylhydrazides, mercapto1,2,4-triazole, oxadiazoline and $\alpha$-amino ester precursors: synthesis and antimicrobial activity," Journal of the Brazilian Chemical Society, vol. 14, no. 5, pp. 790-796, 2003.

[40] J. L. Rios and M. C. Recio, "Medicinal plants and antimicrobial activity," Journal of Ethnopharmacology, vol. 100, no. 2, pp. 8084, 2005.

[41] E. S. Amadi, C. A. Oyeka, R. A. Onyeagba, O. C. Ugbogu, and I. Okoli, "Antimicrobial screening of Breynia nivosus and Ageratum conyzoides against dental caries organisms," Journal of Biological Sciences, vol. 7, no. 2, pp. 354-358, 2007.

[42] S. A. Aboaba and E. Yeye, "Studies on phytochemical screening, antimicrobial and toxicity effect of the shoot system of Acalypha segetalis Müell. Arg," African Journal of Pure and Applied Chemistry, vol. 8, no. 12, pp. 191-195, 2014.

[43] A. Wahab, S. Begum, A. Ayub et al., "Luteolin and kaempferol from Cassia alata, antimicrobial and antioxidant activity of its 
methanolic extracts," FUUAST Journal of Biology, vol. 4, no. 1, pp. 1-5, 2014.

[44] K. Lewis and F. M. Ausubel, "Prospects for plant-derived antibacterials," Nature Biotechnology, vol. 24, no. 12, pp. 15041507, 2006.

[45] G. Kapoor, S. Saigal, and A. Elongavan, "Action and resistance mechanisms of antibiotics: A guide for clinicians," Journal of Anaesthesiology Clinical Pharmacology, vol. 33, no. 3, pp. 300305, 2017. 


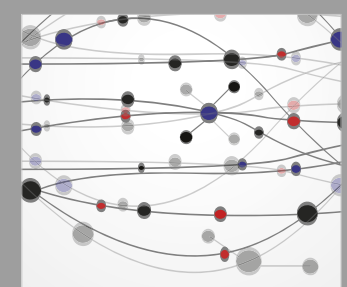

The Scientific World Journal
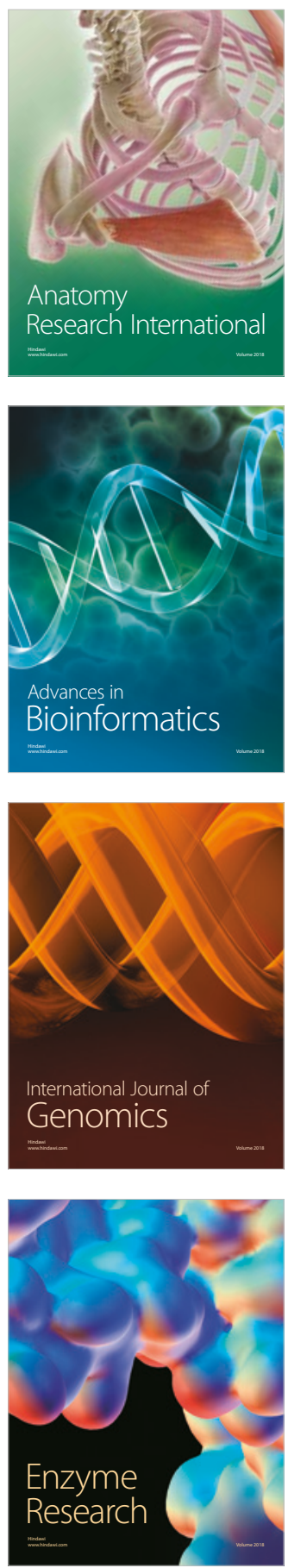
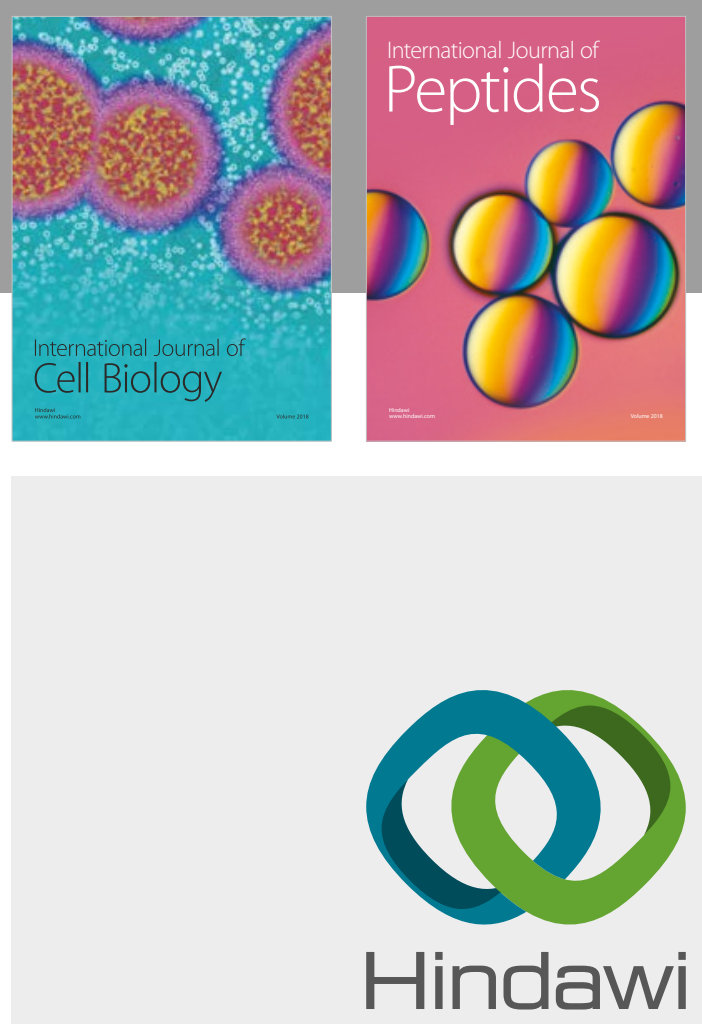

Submit your manuscripts at

www.hindawi.com
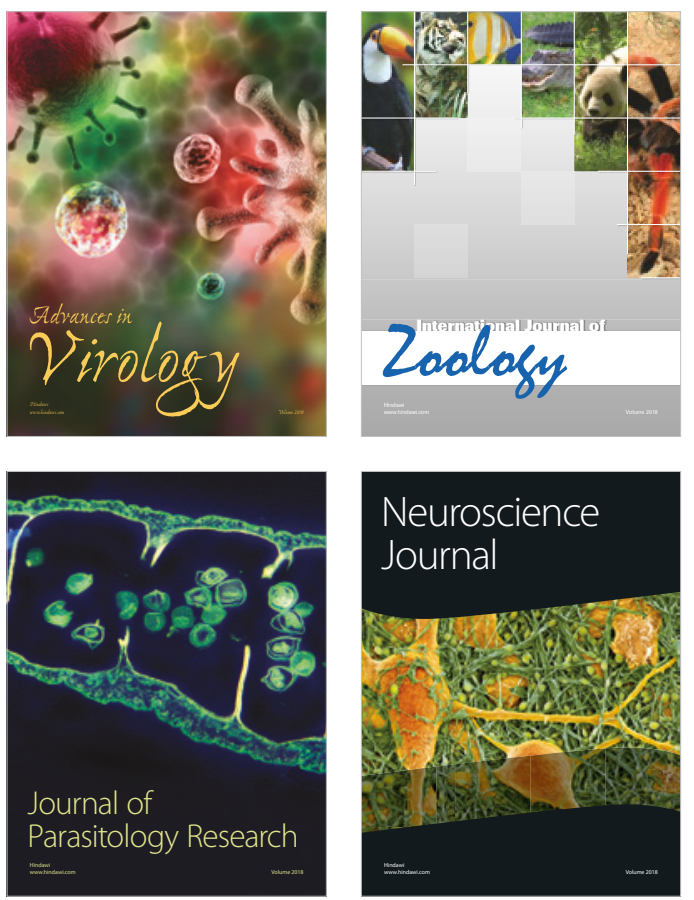
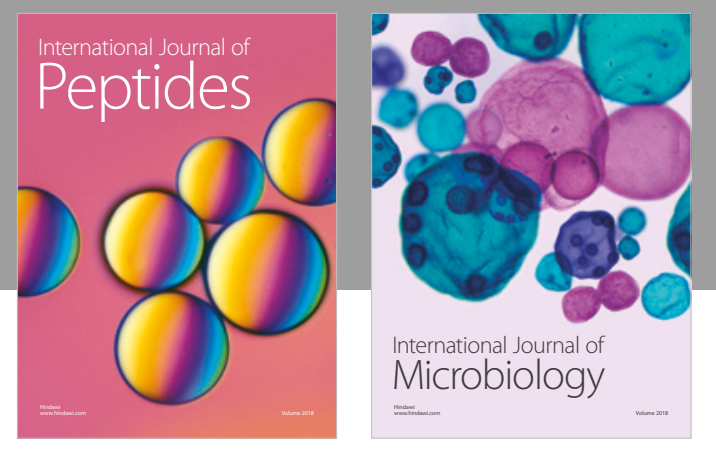

nternational Journal of Microbiology
Journal of
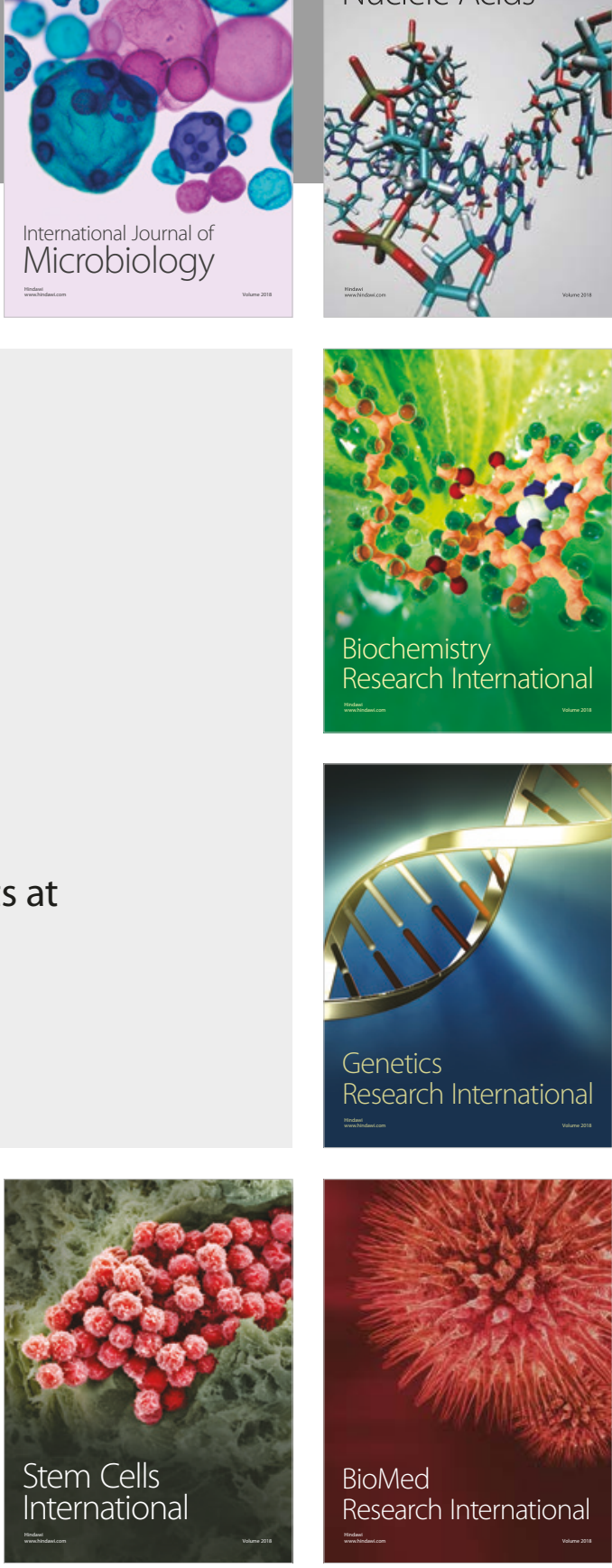
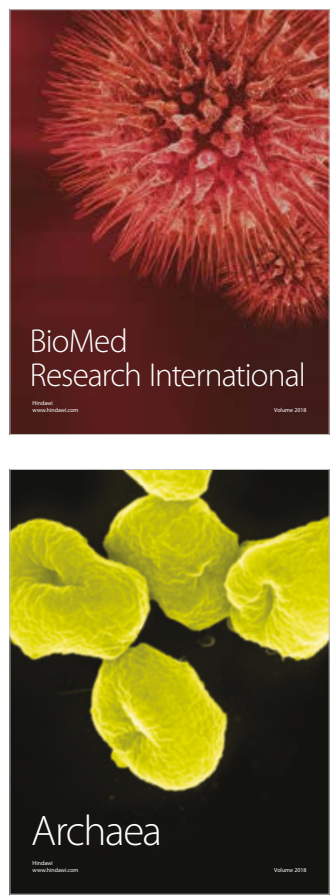